\title{
ANTIDIABETIC ACTIVITY OF BAUHINIA VAHLII Wt. and Arn. (CAESALPINIACEAE) ROOT - A BOTANICAL SOURCE FOR THE AYURVEDA DRUG MURVA
}

\author{
KAMATCHI SUNDARA SARAVANAN*, VARADHARAJAN MADHAVAN
}

Department of Pharmacognosy, Faculty of Pharmacy, M. S. Ramaiah University of Applied Sciences, Bengaluru, Karnataka, India. Email: sundarksharan@gmail.com

Received: 08 January 2019, Revised and Accepted: 19 February 2019

\section{ABSTRACT}

Objective: The objective of this study was to evaluate the antidiabetic potential of Bauhinia vahlii Wt. and Arn. (Caesalpiniaceae) root, a botanical source for Murva (Ayurveda drug).

Methods: Ethanol extract of B. vahlii root (EEBVR) and aqueous extract of B. vahlii root (AEBVR) prepared were subjected for acute toxicity study adopting Organisation for Economic Cooperation and Development guidelines. Antidiabetic property of EEBVR and AEBVR was screened against Streptozotocin-nicotinamide-induced Diabetes Mellitus (DM). The diabetic animals were administered with standard drug glibenclamide (0.5 mg/kg), EEBVR (200 and $400 \mathrm{mg} / \mathrm{kg}$ ), and AEBVR (200 and $400 \mathrm{mg} / \mathrm{kg}$ ) for 21 days. Fasting blood glucose, serum triglycerides, total cholesterol, liver malondialdehyde, reduced glutathione, and glycogen were estimated along with pancreatic histological analysis.

Results: EEBVR (400 mg/kg) exerted a marked antidiabetic activity among the extracts at the tested doses, as evidenced by considerable reversal of biochemical parameters that were well supported by the histopathological interpretation of pancreas.

Conclusion: This study confirms the antidiabetic potential of B. vahlii root and also its traditional claim in the use of DM.

Keywords: Bauhinia vahlii, Murva, Diabetes, Streptozotocin, Nicotinamide.

(C) 2019 The Authors. Published by Innovare Academic Sciences Pvt Ltd. This is an open access article under the CC BY license (http://creativecommons. org/licenses/by/4. 0/) DOI: http://dx.doi.org/10.22159/ajpcr.2019.v12i4.31373

\section{INTRODUCTION}

Diabetes Mellitus (DM) is one of the common metabolic disorders significantly affecting the world population, and according to the International Diabetes Federation's, $80 \%$ of the world diabetic population is anticipated from low- and middle-income countries in 2030 [1]. The treatment of DM is oriented toward oral glucoselowering agents such as sulfonylureas, biguanides, thiazolidinediones, and alpha-glucosidase inhibitors in case of non-insulin dependent type and insulin therapy if it is of insulin dependent. Limitation of medical management of diabetes is the incidence of adverse effects, so many of the research institutes and pharmaceutical industries are involved in drug development to hit on molecules with good therapeutic potential and less adverse events.

Traditional systems of medicine have taken care of the health needs of the people [2], and various herbs are documented for their promising results in managing various systemic disorders including diabetes. The dearth in reports of standardization with reference to efficacy, safety, and usage poses a major challenge in the development of those traditional herbal medicines. Murva is a widely used drug in Ayurveda and the formulations containing Murva root are reported to be used in the treatment of Meha, Prameha (prediabetes disorder), Madhumeha (diabetes), Kustha (skin diseases), Netra roga (eye diseases), Pandu (anemia), Jvara (fever), Hrdroga (Cardiac disorders), and Gulma (abdominal disorders) [3]. Although the accepted botanical source for Murva is Marsdenia tenacissima (Roxb.) Moon (Asclepiadaceae) [4], there are many other plant species being used in the same drug name and one such species is Bauhinia vahlii Wt. and Arn. (Caesalpiniaceae) [5]. Antibacterial and antifungal property of B. vahlii root [6] has already been reported, while there is no comprehensive report on the antidiabetic property [7]. Hence, the present study was planned to explore the antidiabetic activity of $B$. vahlii root in Streptozotocin (STZ)-nicotinamide (NA)-induced DM. This work will also substantiate the traditional use and provide an alternate source for the drug Murva in Ayurveda.

\section{MATERIALS AND METHODS}

\section{Plant material}

B. vahlii root was collected during September 2011 from Tirumala hills, Andhra Pradesh, India and authenticated using local flora. A voucher herbarium specimen ( $S S$ 048) was prepared as per the standard procedure [8] and deposited at the Department of Pharmacognosy, Faculty of Pharmacy, M. S. Ramaiah University of Applied Sciences, Bengaluru, for future reference.

\section{Chemicals and reagents}

Biochemical assay kits for the estimation of serum triglycerides (TG) and total cholesterol (TC) were procured from Agappe Diagnostics, India. STZ was obtained from Spectrochem Pvt. Ltd., India. All other chemicals and solvents used were of analytical grade.

\section{Extraction}

$B$. vahlii root was cleaned, shade dried, and coarsely powdered. Ethanol extract of B. vahlii root (EEBVR) was prepared using 95\% v/v ethanol, and aqueous extract of $B$. vahlii root (AEBVR) was prepared by macerating in distilled water with $0.25 \% \mathrm{v} / \mathrm{v}$ of chloroform. Both the extracts were concentrated to dryness and refrigerated till further use.

\section{Phytochemical screening}

A preliminary phytochemical analysis of EEBVR and AEBVR was performed for the identification of various phytoconstituents using standard procedures [9].

\section{Animals}

Albino Wistar rats of both sex in the weight range of 220-250 g were housed at $24 \pm 2{ }^{\circ} \mathrm{C}$, fed with standard pellet diet and water ad libitum. 
The Institutional Animal Ethics Committee approved the protocol of this study (Approval No.: MSRCP/P-12/011).

\section{Acute toxicity}

Acute oral toxicity of EEBVR and AEBVR was studied as per the Organization for Economic Cooperation and Development 423 guidelines [10]. A single oral dose of $2000 \mathrm{mg} / \mathrm{kg}$ was administered to overnight fasted animals and observed continuously for first $3 \mathrm{~h}$ for its behavioral profile, neurological profile, and autonomic response and thereafter for every $24 \mathrm{~h}$ till 21 days.

\section{Antidiabetic activity \\ Induction of diabetes and treatments}

Diabetes was induced in overnight fasted animals by a single dose of freshly prepared NA (110 mg/kg, i.p.)) in normal saline followed by STZ ( $45 \mathrm{mg} / \mathrm{kg}$, i.p.), in citrate buffer 15 min later. After 4 days of STZ-NA administration, the animals with fasting blood glucose levels $>200 \mathrm{mg} / \mathrm{dl}$ were considered diabetic [11,12]. A total of 42 diabetic animals were divided into seven groups $(n=6)$ : Group I, vehicle control; Group II, diabetic control (STZ-NA); Group III, standard treated, glibenclamide $(0.5 \mathrm{mg} / \mathrm{kg})$; Groups IV and V, EEBVR administered (200 and $400 \mathrm{mg} / \mathrm{kg}$ ); and Groups VI and VII, AEBVR treated (200 and $400 \mathrm{mg} / \mathrm{kg}$ ). The standard drug, EEBVR, and AEBVR at the prescribed doses were administered once daily orally to the respective group animals for 21 days. The animals were weighed, and the fasting blood glucose levels were estimated using blood glucose test strips on the $7^{\text {th }}, 14^{\text {th }}$, and $21^{\text {st }}$ days. After the assessment of fasting blood glucose levels on the $21^{\text {st }}$ day, blood was collected by retro-orbital plexus and centrifuged at $2500 \mathrm{rpm}$ for $10 \mathrm{~min}$ to estimate TG and TC [13]. Later, the animals were sacrificed under ether anesthesia to isolate liver for the estimation of malondialdehyde (MDA), reduced glutathione (GSH), glycogen levels $[14,15]$, and pancreas for histopathological studies.

\section{Statistical analysis}

The results obtained were statistically analyzed by one-way ANOVA followed by Tukey's Kramer multiple comparison tests and the values were expressed as Mean \pm SEM $(n=6)$. The analysis was carried out using GraphPad InStat V-3 software.

\section{RESULTS}

\section{Phytochemical screening}

The preliminary phytochemical screening of $B$. vahlii root extract revealed the presence of phytosterols, fats, proteins, carbohydrates, saponins, phenolic compounds, and tannins.

\section{Acute toxicity study}

EEBVR and AEBVR were found to be safe without any signs of toxicity at $2000 \mathrm{mg} / \mathrm{kg}$. Hence, $1 / 10^{\text {th }}(200 \mathrm{mg} / \mathrm{kg})$ and $1 / 5^{\text {th }}(400 \mathrm{mg} / \mathrm{kg})$ of the tested dose were selected for the antidiabetic study.

\section{Antidiabetic activity}

STZ-NA administration resulted in the elevation of blood glucose, serum TG, TC, liver MDA, decrease in body weight, depletion of liver GSH, and glycogen levels. The animals administered with the standard drug glibenclamide showed a significant reduction $(\mathrm{p}<0.001)$ in the fasting blood glucose levels on the $7^{\text {th }}$ day. The diabetic animals treated with EEBVR and AEBVR at both the test doses exhibited significant lowering $(p<0.001)$ of fasting blood glucose levels on 14 days itself compared to diabetic control animals (Table 1).

Diabetes-induced elevation of serum TG and TC was significantly lowered $(\mathrm{p}<0.001)$ in the animals treated with glibenclamide. Both the tested doses of EEBVR and $400 \mathrm{mg} / \mathrm{kg}$ of AEBVR exerted significant reduction $(\mathrm{p}<0.001)$ in TG and TC levels compared to animals in diabetic control. AEBVR at a low dose $(200 \mathrm{mg} / \mathrm{kg})$ did not exert any significant reduction in TG and TC levels (Table 2).

The altered levels of liver GSH, MDA, and glycogen were significantly normalized $(p<0.001)$ in animals with glibenclamide treatment. Treatment of animals with EEBVR $400 \mathrm{mg} / \mathrm{kg}(\mathrm{p}<0.001)$ and $200 \mathrm{mg} / \mathrm{kg}$ $(p<0.05)$, AEBVR $400 \mathrm{mg} / \mathrm{kg}(\mathrm{p}<0.05)$ caused significant elevation of GSH, while AEBVR administration with $200 \mathrm{mg} / \mathrm{kg}$ was not significant in rising the GSH level. A significant reduction in MDA was observed with EEBVR (200 mg/kg and $400 \mathrm{mg} / \mathrm{kg}, \mathrm{p}<0.001)$ and AEBVR (200 mg/kg, p<0.05; $400 \mathrm{mg} / \mathrm{kg}, \mathrm{p}<0.001)$. The glycogen levels were increased significantly in EEBVR $(200 \mathrm{mg} / \mathrm{kg}$ and $400 \mathrm{mg} / \mathrm{kg}$, p<0.001), AEBVR $(400 \mathrm{mg} / \mathrm{kg}, \mathrm{p}<0.05)$ received animals while the elevation of glycogen level in AEBVR $(200 \mathrm{mg} / \mathrm{kg}$ ) was not significant (Table 3).

The restoration of body weight in animals treated with standard, EEBVR, and AEBVR at both the doses was found significant $(\mathrm{p}<0.001)$ on the $21^{\text {st }}$ day against diabetes-induced weight loss (Table 4).

\section{Histopathological study}

The pancreas histopathology of vehicle control animals showed normal lobular architecture with acinar cells surrounding the islet cells. The acinar cells were embedded with intact interlobular connective tissue and normally arranged polygonal cells (Fig. 1a). The diabetic control animals exhibited congested, dilated blood vessels with inflammatory infiltration and degenerated islet cells (Fig. 1b). The standard drugtreated animals revealed partially regenerated islet cells bounded by acinar cells (Fig. 1c). The pancreas of animals administered with EEBVR $200 \mathrm{mg} / \mathrm{kg}$ showed inflammatory infiltrations, acinar with cellular residues (Fig. 1d); whereas EEBVR $400 \mathrm{mg} / \mathrm{kg}$ treated animals showed mild congestion in blood vessels with normal acinar cells (Fig. 1e). Vacuolated cells within the islets, congested blood vessels with inflammatory exudates and degenerated islets were observed in animals that received AEBVR $200 \mathrm{mg} / \mathrm{kg}$ (Fig. 1f), while normal acinar cells with mild regeneration of islet cells were noticed in AEBVR $400 \mathrm{mg} / \mathrm{kg}$ treated animals (Fig. 1g).

Table 1: Effect of Bauhinia vahlii on fasting blood glucose levels in STZ-NA-induced diabetic animals

\begin{tabular}{|c|c|c|c|c|}
\hline Group and treatment & 0 day $(\mathrm{mg} / \mathrm{dl})$ & $7^{\text {th }}$ day $(\mathrm{mg} / \mathrm{dl})$ & $14^{\text {th }}$ day $(\mathrm{mg} / \mathrm{dl})$ & $21^{\text {st }}$ day $(\mathrm{mg} / \mathrm{dl})$ \\
\hline \multicolumn{5}{|l|}{ Vehicle control } \\
\hline Vehicle & $98.83 \pm 2.44$ & $99.33 \pm 1.25$ & $99.83 \pm 1.85$ & $99.16 \pm 1.15$ \\
\hline \multicolumn{5}{|l|}{ Diabetic control } \\
\hline Vehicle & $272.16 \pm 5.98^{\#}$ & $299.83 \pm 8.00^{\#}$ & $323.50 \pm 7.27^{\#}$ & $357.33 \pm 6.15^{\#}$ \\
\hline \multicolumn{5}{|l|}{ Glibenclamide } \\
\hline $0.5 \mathrm{mg} / \mathrm{kg}$ & $280.66 \pm 4.93$ & $228.83 \pm 1.32^{* * *}$ & $179.50 \pm 1.02^{* * *}$ & $132.33 \pm 1.20^{* * *}$ \\
\hline \multicolumn{5}{|l|}{ EEBVR } \\
\hline $400 \mathrm{mg} / \mathrm{kg}$ & $276.33 \pm 5.06$ & $261.16 \pm 2.18^{* *}$ & $242.83 \pm 2.73^{* * *}$ & $222.16 \pm 2.33^{* * *}$ \\
\hline \multicolumn{5}{|l|}{ AEBVR } \\
\hline $200 \mathrm{mg} / \mathrm{kg}$ & $275.50 \pm 2.48$ & $273.33 \pm 1.89^{*}$ & $257.16 \pm 1.42^{* * *}$ & $237.83 \pm 2.96^{* * *}$ \\
\hline $400 \mathrm{mg} / \mathrm{kg}$ & $276.33 \pm 4.90$ & $271.50 \pm 2.11^{*}$ & $255.16 \pm 1.19^{* * *}$ & $235.16 \pm 3.03^{* * *}$ \\
\hline
\end{tabular}

Values are expressed as Mean \pm SEM. Data were analyzed by one-way ANOVA followed by Turkey's Kramer Multiple Comparison test. " $\mathrm{p}<0.001$, compared to vehicle control. ${ }^{*} \mathrm{p}<0.05,{ }^{* *} \mathrm{p}<0.01,{ }^{* * *} \mathrm{p}<0.001$, compared to diabetic control group. STZ: Streptozotocin, NA: Nicotinamide, EEBVR: Ethanol extract of $B$. vahlii root, AEBVR: Aqueous extract of $B$. vahlii root, SEM: Standard error of mean 


\section{DISCUSSION}

STZ is a glycoside from Streptomyces achromogenes possessing the potent alkylating property and selective pancreatic islet beta cell cytotoxicity. The uptake of STZ by $\beta$ cells results in the formation of superoxide radicals. Moreover, STZ also liberates nitric oxide leading to the destruction of $\beta$-cells. NA was intraperitoneally administered to activate the polymeric adenosine diphosphate ribose synthase that repairs the damaged deoxyribonucleic acid caused by STZ $[12,16]$ thus creating a model similar to type $2 \mathrm{DM}$.

Glibenclamide acts by inhibiting ATP dependent potassium channels of beta cells in the pancreas, augments insulin secretion and increase the insulin-dependent tissues sensitivity resulting in glucose utilization [17]. The significant reduction in fasting blood glucose levels of animals treated with EEBVR and AEBVR may be attributed to the supportive action of drug extracts in glucose utilization.

DM is associated with a remarkable increase in serum TG and TC levels. Insulin activates lipoprotein lipase for the hydrolysis of TG; hence, its deficiency causes less inactivation of lipoprotein lipase and a rise in TG level is noticed. In addition, insulin deficiency is also associated with an increase in serum TC due to metabolic abnormalities [18]. Treatment of animals with EEBVR and AEBVR significantly reduced the serum TG and TC level compared to diabetic control animals.

GSH is an endogenous antioxidant very much essential for cellular protection [19]. EEBVR and AEBVR treatment of animals exhibited

Table 2: Effect of Bauhinia vahlii on serum TG and TC in STZ-NA-induced diabetic animals

\begin{tabular}{lll}
\hline Group and treatment & TG $(\mathbf{m g} / \mathbf{d l})$ & TC $(\mathbf{m g} / \mathbf{d l})$ \\
\hline $\begin{array}{l}\text { Vehicle control } \\
\quad \text { Vehicle }\end{array}$ & $79.83 \pm 1.51$ & $74.16 \pm 2.27$ \\
$\begin{array}{l}\text { Diabetic control } \\
\text { Vehicle }\end{array}$ & $159.16 \pm 4.12^{\#}$ & $130.16 \pm 3.35^{\#}$ \\
Glibenclamide & & \\
$\quad 0.5 \mathrm{mg} / \mathrm{kg}$ & $92.66 \pm 1.47^{* * *}$ & $83.16 \pm 2.53^{* * *}$ \\
EEBVR & $134.16 \pm 1.92^{* * *}$ & $111.16 \pm 1.92^{* * *}$ \\
$\quad 200 \mathrm{mg} / \mathrm{kg}$ & $123.33 \pm 1.39^{* * *}$ & $103.33 \pm 2.82^{* * *}$ \\
$\quad \begin{array}{l}400 \mathrm{mg} / \mathrm{kg} \\
\text { AEBVR }\end{array}$ & $148.66 \pm 1.49$ & $123.33 \pm 1.83$ \\
$200 \mathrm{mg} / \mathrm{kg}$ & $136.16 \pm 1.30^{* * *}$ & $110.33 \pm 0.88^{* * *}$ \\
$400 \mathrm{mg} / \mathrm{kg}$ &
\end{tabular}

Values are expressed as Mean \pm SEM. Data were analyzed by one-way ANOVA followed by Turkey's Kramer Multiple Comparison test. " $\mathrm{p}<0.001$, compared to vehicle control. ${ }^{*} \mathrm{p}<0.05,{ }^{* *} \mathrm{p}<0.01,{ }^{* * *} \mathrm{p}<0.001$, compared to diabetic control group. TG: Triglycerides, TC: Total cholesterol, STZ: Streptozotocin, NA: Nicotinamide, EEBVR: Ethanol extract of B. vahlii root, AEBVR: Aqueous extract of $B$. vahlii root, SEM: Standard error of mean significant restoration of liver GSH in dose-dependent manner. Lipid peroxidation causes cell membrane destruction by free radicals [19] and the estimation of lipid peroxidation in terms of MDA levels directly reflects the extent of oxidative damage occurred. The elevation in

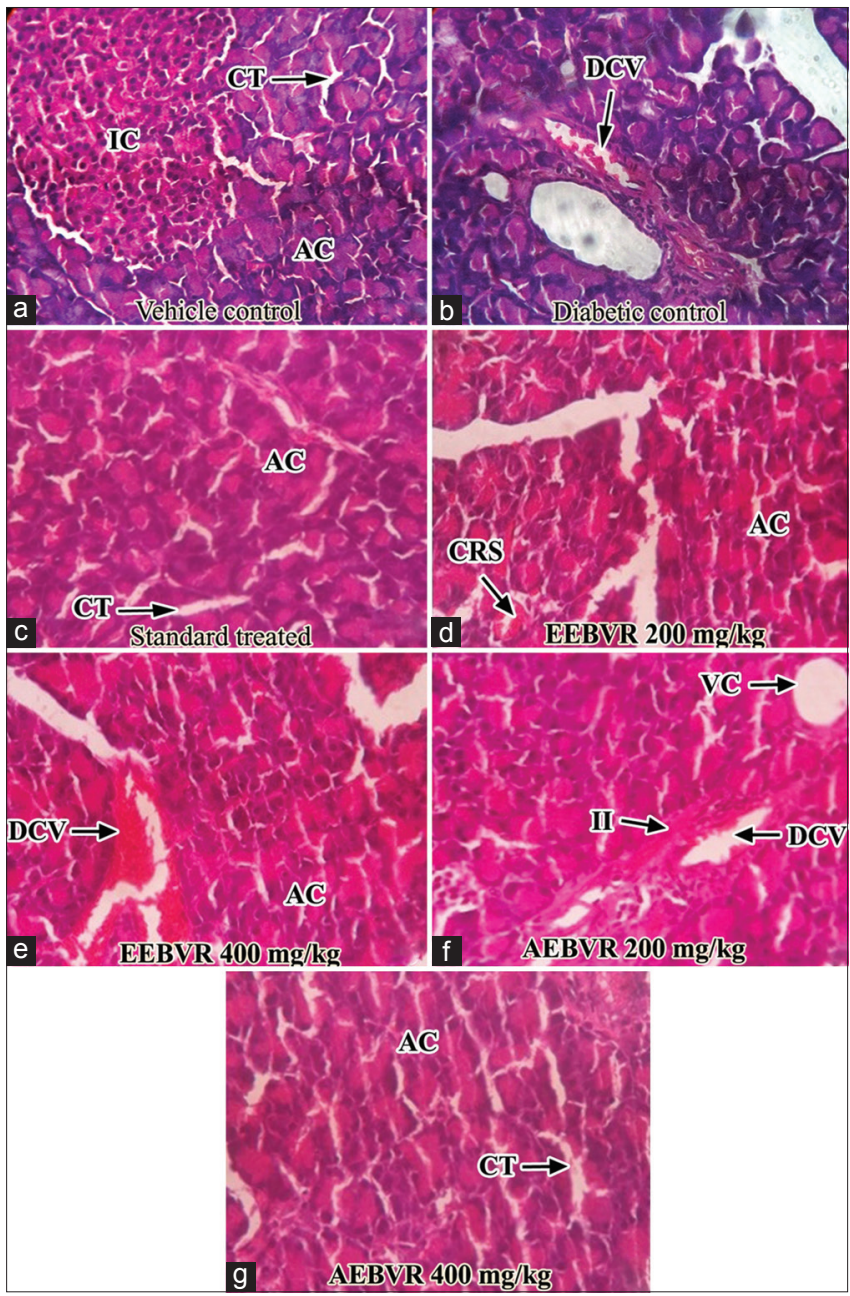

Fig. 1: (a-g) Pancreas histopathology of animals treated with EEBVR and AEBVR in STZ-NA-induced diabetes $(\times 40)$.

IC: Islet cells, CT: Connective tissue, AC: Acinar cells, DCV:

Dilated, congested vessel, CRS: Cellular residue, VC: Vacuole, II:

Inflammatory infiltration, STZ: Streptozotocin, NA: Nicotinamide, EEBVR: Ethanol extract of B. vahlii root, AEBVR: Aqueous extract of $B$. vahlii root

Table 3: Effect of Bauhinia vahlii on liver GSH, MDA, and Glycogen in STZ-NA-induced diabetic animals

\begin{tabular}{llll}
\hline Group/treatment & GSH (nm/100 $\mathbf{~ m g ~ t i s s u e ) ~}$ & MDA (TBARS nm/100 $\mathbf{~ m g ~ t i s s u e ) ~}$ & Glycogen (mg/100 mg tissue) \\
\hline $\begin{array}{l}\text { Vehicle control } \\
\text { Vehicle }\end{array}$ & $65.07 \pm 1.29$ & $0.20 \pm 0.02$ & $6.53 \pm 0.29$ \\
$\begin{array}{l}\text { Diabetic control } \\
\text { Vehicle }\end{array}$ & $29.65 \pm 0.53^{\#}$ & $0.43 \pm 0.02^{\#}$ & $1.88 \pm 0.16^{\#}$ \\
$\begin{array}{l}\text { Glibenclamide } \\
\quad 0.5 \mathrm{mg} / \mathrm{kg}\end{array}$ & $52.81 \pm 1.01^{* * *}$ & $0.22 \pm 0.01^{* * *}$ & $5.12 \pm 0.14^{* * *}$ \\
$\begin{array}{l}\text { EEBVR } \\
200 \mathrm{mg} / \mathrm{kg}\end{array}$ & $36.32 \pm 1.20^{*}$ & $0.30 \pm 0.01^{* * *}$ & $3.75 \pm 0.34^{* * *}$ \\
$400 \mathrm{mg} / \mathrm{kg}$ & $41.97 \pm 2.24^{* * *}$ & $0.25 \pm 0.02^{* * *}$ & $4.29 \pm 0.22^{* * *}$ \\
$\mathrm{AEBVR}$ & $31.38 \pm 0.89$ & & $2.77 \pm 0.20$ \\
$200 \mathrm{mg} / \mathrm{kg}$ & $36.44 \pm 1.92^{*}$ & $0.34 \pm 0.01^{*}$ & $3.24 \pm 0.42^{*}$ \\
\hline $00 \mathrm{mg} / \mathrm{kg}$ & & $0.30 \pm 0.01^{* * *}$ & \\
\hline
\end{tabular}

Values are expressed as Mean \pm SEM, Data were analyzed by one-way ANOVA followed by Turkey's Kramer Multiple Comparison test. " $\mathrm{p}<0.001$, compared to vehicle control, ${ }^{*} \mathrm{p}<0.05,{ }^{* *} \mathrm{p}<0.01,{ }^{* * *} \mathrm{p}<0.001$, compared to diabetic control group. GSH: Reduced glutathione, MDA: Malondialdehyde, STZ: Streptozotocin, NA: Nicotinamide, EEBVR: Ethanol extract of B. vahlii root, AEBVR: Aqueous extract of B. vahlii root, SEM: Standard error of mean 
Table 4: Effect of Bauhinia vahlii on body weight in STZ-NA-induced diabetic animals

\begin{tabular}{ll}
\hline Group/treatment & \% change in weight (g) \\
\hline $\begin{array}{l}\text { Vehicle control } \\
\text { Vehicle }\end{array}$ & $8.11 \pm 0.81$ \\
Diabetic control & \\
$\quad$ Vehicle & $-18.44 \pm 0.38^{\#}$ \\
Glibenclamide & \\
$0.5 \mathrm{mg} / \mathrm{kg}$ & $-3.97 \pm 0.69^{* * *}$ \\
EEBVR & \\
$200 \mathrm{mg} / \mathrm{kg}$ & $-10.28 \pm 0.24^{* * *}$ \\
$400 \mathrm{mg} / \mathrm{kg}$ & $-8.26 \pm 0.45^{* * *}$ \\
$\mathrm{AEBVR}$ & \\
$200 \mathrm{mg} / \mathrm{kg}$ & $-12.13 \pm 0.18^{* * *}$ \\
$400 \mathrm{mg} / \mathrm{kg}$ & $-9.97 \pm 0.55^{* * *}$ \\
\hline
\end{tabular}

Values are expressed as Mean \pm SEM, Data were analyzed by one-way ANOVA followed by Turkey's Kramer Multiple Comparison test. ${ }^{\mathrm{p}}<0.001$, compared to vehicle control, ${ }^{*} \mathrm{p}<0.05,{ }^{* *} \mathrm{p}<0.01,{ }^{* * *} \mathrm{p}<0.001$, compared to diabetic control group. GSH: Reduced glutathione, MDA: Malondialdehyde, STZ: Streptozotocin NA: Nicotinamide, EEBVR: Ethanol extract of B. vahlii root, AEBVR: Aqueous extract of $B$. vahlii root, SEM: Standard error of mean

hepatic MDA levels caused by STZ-NA was significantly brought down in the animals administered with EEBVR and AEBVR.

A decrease in liver glycogen content in diabetic animals was observed which might be due to decreased glycogen synthesis or increased glycogenolysis [20]. This decreased hepatic glycogen in the animals treated with STZ-NA was significantly increased by EEBVR and AEBVR in a dose-dependent fashion.

Diabetes-induced weight loss may be attributed to muscle wasting and catabolism of tissue proteins. A significant reversal of weight loss is observed in animals administered with EEBVR and AEBVR.

The studies reported earlier by various researchers have established the antidiabetic activity of phenolic compounds and tannins [21,22] and saponins $[23,24]$ in DM. The antidiabetic potential of $B$. vahlii against STZ-NA induced diabetes may be ascribed to the presence of the above said phytoconstituents that would have resulted in a significant reduction of fasting blood glucose level and restoration of body weight. Moreover, the depleted liver GSH, glycogen, and the elevated MDA levels were significantly restored as compared to diabetic control animals which suggest the protective action against liver in STZ-NA-induced oxidative stress.

\section{CONCLUSION}

The present work confirms the antidiabetic activity of $B$. vahlii root against STZ-NA-induced DM. Among the extracts screened, EEBVR $400 \mathrm{mg} / \mathrm{kg}$ exhibited a significant effect in lowering blood glucose levels, restoration of animal weight and also in reverting the serum TG, TC levels; liver GSH, MDA, and glycogen content. The result also supports the traditional use in the treatment of diabetes and thus provides an alternate source to the Ayurveda drug, Murva.

\section{ACKNOWLEDGMENT}

The authors are grateful to the authorities of Gokula Education Foundation (Medical) and M. S. Ramaiah University of Applied Sciences, Bengaluru for providing facilities and evincing interest in this work.

\section{AUTHOR'S CONTRIBUTIONS}

KSS carried out the experimental work and drafted the manuscript under the supervision of VM.

\section{CONFLICTS OF INTEREST}

There are no conflicts of interest to declare.

\section{REFERENCES}

1. Adeghate E, Schattner P, Dunn E. An update on the etiology and epidemiology of diabetes mellitus. Ann N Y Acad Sci 2006;1084:1-29.

2. Vaidya AD, Devasagayam TP. Current status of herbal drugs in India: An overview. J Clin Biochem Nutr 2007;41:1-11.

3. The Ayurvedic Formulary of India. Part 1. $1^{\text {st }}$ ed. Delhi, India: The Controller of Publications, Government of India; 2003.

4. The Ayurvedic Pharmacopoeia of India. Part 1. $1^{\text {st }}$ ed., Vol. 1. New Delhi, India: Ministry of Health and Family Welfare, Government of India; 2001.

5. Bapalal V. Some Controversial Drugs in Indian Medicine. Varanasi, India: Chaukhambha Orientalia; 1982.

6. Dugasani S, Balijepalli MK, Tandra S, Pichika MR. Antimicrobial activity of Bauhinia tomentosa and Bauhinia vahlii roots. Pharmacogn Mag 2010;6:204-7.

7. Gurudeva MR, Yoganarasimhan SN. Bibliography of medicinal plants of India (Pharmacognosy and Pharmacology). Bangalore, India: Divya Chandra Prakashana; 2009.

8. Jain SK, Rao RR. Field and Herbarium Methods. New Delhi: Today and Tomorrow Printers and Publishers; 1977.

9. Kokate CK. Practical Pharmacognosy. Delhi, India: Vallabh Prakashan; 1999.

10. OECD. Acute oral toxicity. Acute oral toxic class method guideline 423 adopted 23.03.1996. In: Eleventh Addendum to the, OECD, Guidelines for the Testing of Chemicals Organization for Economical Co-Operation and Development. Paris; June, 2000, 2002.

11. Ananda PK, Kumarappan CT, Sunil C, Kalaichelvan VK. Effect of Biophytum sensitivum on streptozotocin and nicotinamide-induced diabetic rats. Asian Pac J Trop Biomed 2012;2:31-5.

12. Petchi RR, Vijaya C, Parasuraman S. Antidiabetic activity of polyherbal formulation in streptozotocin - Nicotinamide induced diabetic wistar rats. J Tradit Complement Med 2014;4:108-17

13. Murali A, Ashok P, Madhavan V. Protective effects of Hemidesmus indicus var. pubescens root extract on paracetamol induced hepatic damage. Spatula DD 2012;2:51-8.

14. Murali A, Ashok P, Madhavan V. Antioxidant activity of leaf of Hemidesmus indicus (L.) R. Br. var. pubescens (W. \& A.) Hk.f. (Periplocaceae) - An in vivo analysis. Spatula DD 2011;1:91-100.

15. Raja S, Ravindranadh K. In vivo antioxidant activity of Limnophila heterophylla and Michelia champaca. IJPPS 2017;9:241-6.

16. Oyedemi S, Bradley G, Afolayan A. Antidiabetic activities of aqueous stem bark extract of strychnoshenningsii gilg in streptozotocinnicotinamide type 2 diabetic rats. Iran J Pharm Res 2012;11:221-8.

17. Attanayake AP, Jayatilaka KA, Pathirana C, Mudduwa LK. Study of antihyperglycaemic activity of medicinal plant extracts in alloxan induced diabetic rats. Anc Sci Life 2013;32:193-8.

18. Kumar R, Pate DK, Prasad SK, Sairam K, Hemalatha S. Antidiabetic activity of alcoholic leaves extract of Alangium lamarckii thwaites on streptozotocin-nicotinamide induced type 2 diabetic rats. Asian Pac J Trop Med 2011;4:904-9.

19. Belhekar Santosh N, Chaudhari Pravin D, Pandhare Ramdas B, Pawar Anil R. Effect of polyherbal and allopolyherbal formulation on streptozotocin-nicotinamide induced diabetic nephropathy in rats. Int J Toxicol Pharmacol Res 2016;8:138-45.

20. Shukla K, Dikshit P, Shukla R, Gambhir JK. The aqueous extract of Withania coagulans fruit partially reverses nicotinamide/streptozotocininduced diabetes mellitus in rats. J Med Food 2012;15:718-25.

21. Elshamy A. Antidiabetic and antioxidant activities of phenolic extracts of Conyza dioscoridis (L.) shoots. Int J Pharm Pharm Sci 2015;7:65-72.

22. Vinayagam R, Jayachandran M, Xu B. Antidiabetic effects of simple phenolic acids: A comprehensive review. Phytother Res 2016;30:184-99.

23. Prabu M, Kumuthakalavalli R. Antidiabetic potential of the oyster mushroom Pleurotus florida (Mont.) singer. Int J Curr Pharm Res 2017; 9:51-4.

24. Singh S, Farswan M, Ali S, Afzal M, Al-Abbasi FA, Kazmi I, et al. Antidiabetic potential of triterpenoid saponin isolated from Primula denticulate. Pharm Biol 2014;52:750-5. 